\title{
Łukasz Biskupski, Miasto Atrakcji. Narodziny kultury masowej na przełomie XIX i XX wieku. Kino w systemie rozrywkowym Łodzi,
}

Narodowe Centrum Kultury, Warszawa 2013, ss. 320 (c) $(1) \odot$

Kilka tygodni temu odbyłam bardzo ciekawą rozmowę z pewnym, zabo pisał artykuł o tym mieście. Ja - bo byłam świeżo po lekturze książki Łukasza Biskupskiego. Rozmowa była - by tak rzec - interdyscyplinarna, ale wnioski, mimo różnych paradygmatów badawczych - podobne. Dla osób zajmujących się filmem Łódź będzie miastem filmowym, za sprawą co oczywiste - Łódzkiej Szkoły Filmowej i ekranowego wizerunku tego miasta utrwalonego przez wielu reżyserów. Nie znaczy to jednak, że jako filmoznawcy nie ulegamy wpływowi schematów kształtujących najbardziej popularny, ale i powierzchowny obraz Łodzi. Jej postrzeganie jest wypadkową kilku rzeczy. Po pierwsze historii tego miasta, której tak naprawdę nie znamy, albo ograniczamy do to fragmentu opisanego najpierw przez Władysława Reymonta w Ziemi obiecanej, a potem sfilmowanego przez Andrzeja Wajdę. Po drugie, powojennej kondycji Łodzi - miasta, które mogło, ale nie stało się symbolem robotniczej Polski.

W 1969 roku Krzysztof Kieślowski zrealizował swój film dyplomowy - dokument pod tytułem $Z$ miasta Eodzi. W bezpretensjonalnie prostej formie reżyser pokazał życie ówczesnej Łodzi z jej malowniczą brzydotą, jej mieszkańców w pracy i w czasie wolnym. Całość kończy się w sposób znaczący - słowami piosenki „Tego miasta nie ma na mapie”. Dla znajomego geografa kultury to zdanie okazało się kluczowe dla opisu sytuacji powojennej Łodzi. Miasto, choć tak bardzo kojarzone z przemysłem, musiało skapitulować wobec robotniczej „potęgi” Katowic i - symbolu nowej PolskiNowej Huty. Aleja Włókniarzy znaczyła mniej niż hałdy węgla i hutnicze piece. Również kulturalnie miasto przegrywało z Warszawą i Krakowem. Na zakupy jeździło się też raczej do stolicy bądź Poznania czy Trójmiasta. Łódź była jakby „nie po drodze”. O kulturowym potencjale i barwnej, roz- 
rywkowej przeszłości miasta na całe dekady zapomniano niemal zupełnie. Wielce paradoksalna to sytuacja, biorąc pod uwagę jak dużym i ważnym ośrodkiem uniwersyteckim Łódź była i jest. Najsłynniejsza uczelnia artystyczna w kraju - Łódzka Szkoła Filmowa - też nie była w stanie zmienić tej sytuacji. Dlatego książka Łukasza Biskupskiego Miasto Atrakcji. Narodziny kultury masowej na przetomie XIX i XX wieku. Kino w systemie rozrywkowym Łodzi wydaje się pozycją nie do przecenienia dla współczesnych badań kulturowych, historyczno-kulturowych, filmoznawczych, czy nawet socjologicznych.

Autor rozpoczyna swoją książkę oryginalnie - od opisu pocztówki przedstawiającej Łódź w 1913 roku, czyli miasto, którego tak naprawdę nie znamy. Biskupski pisze:

Kolorowana pocztówka wydana w drukarni Jozefa Ostrowskiego z tego samego roku pokazuje róg ul. Przejazd (Tuwima) i ul. Piotrkowskiej. [...] To właśnie to skrzyżowanie co wieczór kinematografy zalewały migającym światłem. Większość iluzjonów zlokalizowanych było w ścisłym centrum, ale działały jeszcze skierowane do uboższej klienteli sale projekcyjne na Chojnach i Bałutach. W 1913 roku, 17 lat po pierwszej demonstracji kinematografu w Helenowie, elitarnym ogrodzie dla łódzkiej burżuazji, kino na trwałe wpisało się w kulturowy i przestrzenny pejzaż miasta. Tuż przed wybuchem I wojny światowej w ponad półmilionowej Łodzi działało kilkanaście kin, w tym dwa luksusowe kinoteatry, trzy kinematografy uznawane za pierwszorzędne oraz co najmniej dziewięć mniej prestiżowych lokali organizujących za opłatą projekcje filmowe. Chodzenie do kina stało się powszechną praktyką konsumpcyjną i sposobem na manifestację miejskiego stylu życia. Kino dostarczało poruszających doznań estetycznych nie tylko na ekranach, ale także na scenie wielkiego spektaklu miasta. Budynki kinematografów wraz z oświetleniem ulicznym, reklamami czy tramwajami współtworzyły wielkomiejski krajobraz ${ }^{1}$.

Już zatem sam wstęp narzuca czytelnikowi dominantę opisu Łodzi z przełomu XIX i XX wieku - miasto z książki Biskupskiego jest niczym multipleks, który gwarantuje rozrywkę większości jego mieszkańców.

${ }^{1}$ Łukasz Biskupski, Miasto Atrakcji. Narodziny kultury masowej na przetomie XIX i XX wieku. Kino w systemie rozrywkowym Łodzi, Warszawa 2013, s. 15, 16-17. 
To multipleks egalitarny, tak pod względem dostępności, jak i proponowanego repertuaru. Autor publikacji nie pozwala czytelnikowi jednak zapomnieć, że multipleks to zjawisko także biznesowe. Kontekst ekonomiczny jest dla jego analizy niezwykle istotny. Ekonomiczne rudymenty konstytuują tu rozwój przemysły filmowego i rozwój samej Łodzi, jako - zgodnie z tytułem - miasta atrakcji. Biskupski stwierdza dobitnie:

Kino jest przejawem fordyzmu w sferze kultury, wzorcowym przykładem nowoczesnego przemysłu kultury - masowo i mechanicznie wytwarzanej formy rozrywki, która, inaczej niż wysokonakładowa prasa, osiągnęła globalny zasięg dzięki niezależności niemego kina od języka. ${ }^{2}$

W ten oto sposób otwiera polskie badania filmoznawcze na Nową Historię Kina, która - choć obecna już od dłuższego czasu w humanistyce i naukach o sztuce Zachodniej Europy i USA - nie mogła do tej pory zaistnieć jako równoprawna w naszym historyczno-filmowym dyskursie. Autor jest tu bardzo radykalny, stwierdza nawet „Chciałbym przepędzić widmo X muzy". W swoim krytycznym spojrzeniu na tradycyjne metodologie badawcze jest niczym polski Truffaut. Sporą cześć jego wywodu można by zatytułować, parafrazując francuskiego reżysera, „O pewnej przypadłości polskich badań nad historią kina”. Udowadniając zalety przyjętej przez siebie perspektywy badawczej, Biskupski bardzo rozbudowuje część teoretyczną swojej pracy, co jest niepotrzebne. To, co ma do powiedzenia na temat filmowej Łodzi, wystarcza, by udowodnić słuszność jego decyzji. Nieco rozwlekła refleksja teoretyczna sprawia, że tracimy momentami kontakt z tym, co najważniejsze - $\mathrm{z}$ samym miastem $\mathrm{i}$ jego kulturową historią, z przestrzenią, w której powstawała. Bo, jak słusznie konstatuje Biskupski, „narracja historyczna powinna brać pod uwagę, że przestrzeń ma znaczenie", przestrzeń niezwykłego, ale i bardzo konkretnego miejsca. Walczy zatem ze stereotypem Łodzi - „miastem geszeftu”. Woli ją jako „miasto osobliwości”, performansu i spektaklu, preferujące określone praktyki kulturowe, podobne wielu innym miejscom w Europie. Autor upomina się o wprowadzenie do polskiej narracji kulturowej „tego co miejskie, codzienne i niskie”, tych

${ }^{2}$ Ibidem. s. 24. 
obszarów i zjawisk, których kulturotwórcze znaczenie jest od dawna oczywiste dla badaczy na zachodzie naszego kontynentu i w USA, a których my - przywiązani do artystycznego, wartościującego paradygmatu badań nad kulturą - nadal się obawiamy, choć, paradoksalnie, fundamenty nowoczesnej polskiej kultury - jak zauważa Biskupski - mają miejską, codzienną, popularną proweniencję. Lektura ksiązi dowodzi niezbicie, że istnienia kina i filmu w Polsce nie ukonstytuowały dzieła Griffitha, Langa czy Sjöströma, ale ludzie, sytuacje i miejsca (właśnie miejsca!), w których rozrywka, a nie sztuka, była najważniejsza. To „kultura atrakcji” - jak nazywa ją autor - wywalczyła sobie miejsce w miejskiej przestrzeni. Jej znaczenie w kształtowaniu tej przestrzeni udokumentował w sposób niezwykły. Ikonografia i zgromadzone przez badacza dokumenty (od notatek prasowych, programów wydarzeń artystycznych, po dane z archiwów policyjnych) to materiał doskonale uzupełniający jego, i tak już precyzyjną i szczegółową, opowieść o Łodzi z przełomu wieków.

Do rozważań na temat kina sensu stricte przechodzi Biskupski dość późno (nie bez powodu zreszta), ale od razu mocno akcentuje ich charakter. Na przykład braci Krzemińskich, uważanych przez wielu historyków kina za założycieli pierwszego kina na ziemiach polskich (a przez innych zupełnie pomijanych), nazywa „reprezentantami ówczesnej branży rozrywkowej”. Działalność braci Krzemińskich jest doskonałą egzemplifikacją tezy, że powstanie kina i sztuki ruchomych obrazów to efekt konkretnego procesu, który rozpoczął się, gdy ludzie zapragnęli utrwalić obraz w ruchu, a następnie zaprezentować to innym ludziom. Kino nie powstało w artystycznej technicznej i ekonomicznej próżni. Autor Kina Atrakcji opisuje ten proces i jego wczesny efekt bardzo dokładnie i równie atrakcyjnie - jakby na potwierdzenie tytułu. Książka Łukasza Biskupskiego to opowieść o historii kina i miasta. W równej mierze naszemu - polskiemu - kinu i Łodzi ta książka jest bardzo potrzebna. Autor odnalazł zagubione onegdaj miasto i przywrócił je na kulturalną mapę Polski.

Sylwia Kotos (Toruń) 